\title{
Andekuse kui haridusliku erivajaduse tähenduse konstrueerimine Eesti muutunud õpikäsituse kontekstis
}

\author{
Halliki Põlda ${ }^{a^{1}}$, Katrin Aava ${ }^{\mathbf{a}}$ \\ a Tallinna Ülikooli humanitaarteaduste instituut
}

\begin{abstract}
Annotatsioon
Eesti uus haridusstrateegia rõhutab muutunud õpikäsituse raames vajadust toetada õppija individuaalset ja sotsiaalset arengut, tuues samas kitsaskohana välja, et õppijate erivajadusi, sh eri tüüpi andekust, ei märgata ega väärtustata. Samuti on PISA uuringutes Eesti probleemina nimetatud vähest tööd andekatega. Siinse uurimuse eesmärk on kirjeldada, milliste keeleliste valikutega konstrueerivad hariduslikke erivajadusi, eriti andekust, haridusvaldkonna sidusrühmad. Fookusgrupi intervjuudega kogutud materjali analüüsist kriitilise diskursuseanalüüsi meetodil selgub, et hariduslikke erivajadusi seostatakse eelkõige eri- ja erakoolidega, mitte muutunud õpikäsitusega ehk individuaalse lähenemisega õppijale. Andekust nähakse pigem kaasasündinud isikuomadusena kui arengulise protsessina. Andekad paigutatakse sotsiaalse hierarhia tippu (geeniused) või kõige madalamale positsioonile (nohikud, tõrjutud). Neid käsitletakse teistest õppijatest eraldatud rühmana, kelle jaoks pole ressursse, kes saadetakse olümpiaadile, klassiruumist välja.
\end{abstract}

Võtmesõnad: hariduslik erivajadus, andekus, andekas õppija, muutunud õpikäsitus, kriitiline diskursuseanalüüs

\section{Uuringu üldine taust}

Euroopa Liidu ja ka Eesti hariduspoliitika üks peamisi põhimõtteid on kõigi õpilaste arendamine vastavalt nende võimetele, sh märgates ja arvestades hariduslikke erivajadusi (HEV). Eesti elukestva õppe strateegias 2020 on selle põhimõtte alusel sõnastatud uus õpikäsitus, millele viidatakse kui õppija individuaalset ja sotsiaalset arengut toetavale ning õpioskusi, loovust ja ettevõtlikkust arendavale õpikäsitusele, vastandades seda 
traditsioonilisele õpetajakesksele koolipraktikale ning kirjeldades õpetaja ja õpilase muutunud suhteid, kus õpetaja taandub autoriteedi ja teadja rollist ning asetab ennast partneri, ülesandepüstitaja ja julgustaja positsioonile. Traditsiooniline õppevorm asendub uues käsituses rohkem meeskonnatööga, toetades nii õppijate motivatsiooni kui ka õpetajate loomingulisust (Vinter, Slabina, \& Heidmets, 2015).

Õpikäsituse muutumist on hinnatud OECD rahvusvahelise õpetamise ja õppimise uuringutes TALIS $(2008,2013)$. Uuendusliku õpikäsitusena kirjeldatakse seal õppeviise, mille keskmes on õppija aktiivsus. Selgub, et kuigi Eesti õpetajad pooldavad uuenduslikku õpikäsitust, kasutatakse klassis valdavalt traditsioonilisi õpetajakeskseid meetodeid (Loogma, 2014; TALIS, 2008). Sama kehtib ka ülikoolide õpetamispraktika kohta (Jõgi, Karu, \& Krabi, 2015). PISA uuringutes on Eesti probleemina välja toodud just puudulik töö andekatega (PISA, 2012; Säälik, 2012). Eesti õpilaste keskmised tulemused on OECD riikidega võrreldes küll head, kuid vähe on tipptasemel saavutusi (Säälik, 2012). Lisaks on Eestis PISA 2012 küsitlusandmete alusel uuritud õpetaja ja õpilase käitumist kui kaht võimalikku õppetööd takistavat mikrokliima tegurit, arvestades seose leidmisel õpilaste sotsiaalmajandusliku tausta varieerumist. Uurimusest ilmnes, et ühelt poolt osutub raskeks õpetada tugevaid ja nõrku ühes klassis ning teiselt poolt ei julgustata õpilasi kasutama kogu oma potentsiaali (Kitsing, Täht, \& Kukemelk, 2015).

Klassis toimuv, sh õpetaja- või õppijakesksete meetodite kasutamine, on mitmeti seotud ideoloogiliste tõekspidamiste ning ühiskondlike suhete ja identiteetidega haridusasutustes. Võim ühiskonnas realiseerub paljuski haridusinstitutsioonide vahendusel, kujundades ühiskonnas suhted ja rollid, millega tagatakse inimeste juurdepääs kultuurilistele ja majanduslikele ressurssidele (Apple, 1996). Eeldused, aga ka piirangud sotsiaalsete identiteetide kujunemiseks loob seejuures haridusdiskursus, mis kujutab endast õppija sotsiaalse kuuluvusega määratletud mehhanismi ning on mõeldud kultuurikontekstist sõltuvate teadmiste valikuliseks loomiseks ja omandamiseks (Bernstein, 1996).

Üks õpilase individuaalse ja sotsiaalse identiteedi kujunemise olulistest teemadest on hariduslikud erivajadused, sealhulgas andekus. Eestis on laste hariduslikud erivajadused riiklikult aktsepteeritud. Haridus- ja Teadusministeeriumi (2016) sõnul „peab riik koole nägemis- ja kuulmispuudega õpilastele, liikumispuudega õpilastele, kellel lisaks liikumispuudele esineb täiendav hariduslik erivajadus, tundeelu- ja käitumishäiretega õpilastele, toimetuleku- ja hooldusõppel olevatele õpilastele ning kasvatuse eritingimusi vajavatele õpilastele". Kuigi ka andekus on põhikooli ja 
gümnaasiumiseaduse (2010) järgi hariduslik erivajadus ${ }^{2}$, puudub Eestis andekate arendamiseks terviklik tugisüsteem. Mitmes Euroopa riigis (nt Soomes, Suurbritannias) andekust erivajadusena ei nähta (vt Laine \& Tirri, 2015; Norwich \& Eaton, 2015). Suurbritannias seisnevad lapse või noore hariduslikud erivajadused vaid eakohastes õpiraskustes või puuetes, st andekust ja suuri võimeid Suurbritannias hariduslike erivajadustena ei käsitleta ${ }^{3}$. Samas Saksamaal on andekus riiklikult toetatud ja hariduspoliitilistes diskussioonides tähtsal kohal (Fisher \& Müller, 2014).

\section{Õppija erivajadused ja andekus teoorias ja praktikas}

Uues õpikäsituses (Eesti elukestva ..., 2014) pööratakse tähelepanu iga õppija arengule ja potentsiaali väljaarendamisele ning väärtustatakse isiksuslikke erinevusi, toetades ka hariduslike erivajadustega õppijat. HEVõppija mõiste viitas esialgu füüsilistest või sensoorsetest puuetest, emotsionaalsetest ja käitumuslikest probleemidest või arengulisest mahajäämusest põhjustatud õpiraskustele (Terasmees, 2015). Praegugi on paljudes riikides arusaam hariduslikest erivajadustest sarnane eelnimetatud käsitusega, ehkki uuemaid uuringuid selles valdkonnas on veel suhteliselt vähe (Norwich \& Eaton, 2015). Hariduslike erivajaduste mõisteväli on tänapäeval siiski teisenenud ja laienenud, tähistades puuete ja õpiraskuste kõrval ka andekust (HKS, 2014, lk 102).

Kuidas üld- või eriandekust hinnata, ei selgu ühestki eelviidatud haridusdokumendist. Maailma praktikas on tavaks defineerida andekust kõrge intelligentsuse kaudu; hariduse kontekstis sõltub andekuse määratlemine paljuski õpetaja hoiakutest ja subjektiivsetest ettekujutustest, milline peaks andekas õppija olema (Freeman, 2011; Strand, 2006). Mitmete uurijate sõnul ei ole siiski olemas kindlaid kriteeriume, kuidas üldse andekust määratleda, ega ka kindlaid andekuse tuvastamise tavasid (Laine \& Tirri, 2015; Mönks \& Pflüger, 2005). Andekus on sotsiaalsest ja kultuurilisest kontekstist sõltuv konstruktsioon, n-ö silt, mida teatud oludes ja kontekstis inimesele külge pannakse (Borland, 1997, 2005; Cigman, 2006; Kaufman \& Sternberg, 2008; Mazzoli Smith \& Campbell, 2012). Ka meie ülesandepüstitus ja valitud metoodika on lähtunud seisukohast, et andekus sotsiaalse konstruktina on

Andekus kui hariduslik erivajadus on esimest korda dokumenteeritud USA haridusameti 1969. aasta määruses (Saul, Sepp, \& Päiviste, 2007).

3 Vt Euroopa Eriõppe ja Kaasava Hariduse Agentuuri koduleht https://www.european-agency. org/country-information/united-kingdom-england/national-overview/identification-ofspecial-educational-needs. 
spetsiifiliste sotsiaalpoliitiliste huvide peegeldus haridussüsteemis (Borland, 2005, lk 3; vt tagapool „Uuringu eesmärk ja probleemipüstitus”).

Läbi ajaloo on siiski püütud leida alust, millele andekuse määratlus toetada. Käsitused on varieerunud: andekust on võrdsustatud pärilike eeldustega (Galton, 1869), käsitletud spetsiifiliste mudelite kontekstis (Gardner, 1993); andekust on kirjeldatud kui süsteemi ja defineeritud arenguliste protsesside tulemina (Renzulli, 1978; Sternberg, 2005). Spetsiifilistest andekusmudelitest on hariduskontekstis enim kõlapinda leidnud Howard Gardneri andelaaditeooria, mis tõstab - samamoodi nagu muutunud õpikäsitus - esile inimeste potentsiaali või eeldusi ning mille järgi inimeste võimed ja oskused jaotuvad andelaadide järgi kognitiivsetesse moodulitesse (Gardner, 1993). Lihtsustatult räägitakse teooria taustal eri liiki andekusest või intelligentsusest. ${ }^{4}$ Gardneri teooria julgustab haridustöötajaid avardama akadeemiliste traditsioonide piire, pöörates tähelepanu sellistele õppimist ja õpiedu mõjutavatele teguritele nagu isiklik motivatsioon, huvi ja enesehinnang, tõstes esile õppijate individuaalsed oskused (Strand, 2006). Andelaade eristavate mudelite kõrval on levinud arusaam, mille kohaselt andekus on eri komponentide koosmõjul toimiv süsteem (Kaufman \& Sternberg, 2008). Näiteks on andekuse osistena nimetatud keskmisest suuremaid võimeid, loovust, motivatsiooni, elutarkust ja intelligentsust (Renzulli, 1978; Sternberg, 2005).

Praegu valdav andekusuurimuste suund keskendub sarnaselt Gardneriga indiviidi potentsiaalile, kuid näeb andekust mitte kui individuaalseid erinevusi sooritustes, vaid kui keskkonnamõjurite toimel omandatud oskuste tulemust (Gagné, 2004). Mõtlemisainet pakuvad fenomeni tähistavad terminid andekus ja talent, mis on osa uurijate sõnul meelevaldsed, kasutud ja vaidlusi tekitavad (Cigman, 2006; Clayton, 2015; Mazzoli Smith \& Campbell, 2012). Ühelt poolt on enamasti sünonüümidena kasutusel olnud andekus ja talent saanud Gagné andekusmudelis uue sisu - andekus tähistab indiviidi sünnipäraseid eeldusi, talent aga arengu- ja õpiprotsessis omandatud võimeid (Gagné, 2004). Teiselt poolt eristuvad mõisted kultuuriti hoopis tähistatava õpivaldkonna poolest. Näiteks eristati andekust ja talenti valdkonnapõhiselt Suurbritannia valitsuse toetatud programmis „National Academy for Gifted and Talented Youth”, kus andekus viitas suurtele võimetele kognitiivsetel aladel, nagu matemaatika, loodusteadused ja keeled, talent tähistas aga võimekust loovaladel, nagu kunst, muusika ja

Teooriat esitleva teose „Frames of mind” esmaväljaandes (1983) nimetab Gardner seitset moodulit, hilisemas väljaandes (1999) on ta lisanud kaheksanda andelaadi ja hiljem (2006) rääkinud üheksast andelaadist või intelligentsuse liigist. 
tants (Casey \& Koshy, 2013; Cigman, 2006; Clayton, 2015; Strand, 2006). Praegu eristabki ingliskeelne maailm andekust ja talenti (väljendiga gifted and talented viidatakse mõlemale anderühmale koos), samas kui paljudes riikides, k.a Eestis, käsitletakse neid sünonüümidena. Eesti hariduses räägitakse andekusest kui erilisest võimekusest mistahes valdkonnas, mitte eraldi andekast ja talendikast õppijast.

Andekuse defineerimise ja tuvastamise kõrval on olnud keskseks küsimuseks, kuidas andekaid arendada ja õpetada, kuidas nende võimete potentsiaali rakendada (Casey \& Koshy, 2013; Cigman, 2006; Mönks \& Pflüger, 2005). Väga headeks tulemusteks võimeliste laste hulka kuuluvad need, kel on mõni allnimetatud võimetest, kas eraldi või kombineeritult:

1) üldine intellektuaalne võimekus;

2) spetsiifiline akadeemiline võimekus;

3) loominguline mõtlemine;

4) liidrivõimed;

5) võimekus tegelda kujutava või näitekunstiga;

6) psühhomotoorne võimekus (USA haridusameti 1969. aasta definitsiooni tõlge, viidatud Saul, Sepp, \& Päiviste, 2007, lk 9 järgi).

Valdkonna pikiuuringute sisuks on olnud andekana määratletud lapse arenguetappide jälgimine ja kirjeldamine ning arutelu andekaid ümbritseva keskkonna, sh koolikeskkonna üle (vt Freeman, 2006). Õpetamispraktika uuringutes kirjeldatakse andekate õpet diferentseerimise kaudu ning õppekava andekate arenguga kohandamise ja individuaalõppe kaudu, rõhutades õpetaja vastutust annete arendamisel (Clayton, 2015; Laine \& Tirri, 2015; Unt, 2005).

\section{Uuringu eesmärk ja probleemipüstitus}

Uue haridusstrateegia kohaselt on Eestis vaja jagatud arusaama sellest, mis teed pidi tuleks liikuda teadmiste- ja innovatsioonipõhise ühiskonna suunas (Eesti elukestva ..., 2014). Enim ongi sellega seotud just haridusvaldkonna inimesed - hariduse sidusrühmad, kellel lasub ametialane vastutus ja kes on seega haridusdiskursuse kujundajad. Eestis tehtud uuringutes on analüüsitud, kuidas konstrueeritakse hariduslikke erivajadusi (nt Terasmees, 2015) ja andekust (nt Põlda, 2014, 2015) meedias. Andekust on käsitletud peamiselt siiski eraldiseisva fenomenina ja uuritud subjekti tasandilt (Sepp, 2010; Unt, 2005). Praeguses uurimuses keskendume haridusvaldkonna vastutavate isikute arusaamadele hariduslikest erivajadustest, tõstes erivajadusena fookusesse andekuse, ja analüüsime kvalitatiivselt nende 
arusaamade ühiskondlikke tähendusi Eesti muutuvas hariduskontekstis. Uurimisprobleem on, kas õppijakeskne muutuv õpikäsitus kajastub hariduse sidusrühmade arusaamades ning kuidas need sidusrühmad konstrueerivad andekuse tähendust, väljendavad agentsust (vt „Metoodiline raam") ja kujundavad haridussfääri suhtlejate rolle. Probleemist lähtudes püstitasime järgmised uurimisküsimused.

1. Kuidas nimetavad ja milliste diskursuste kaudu konstrueerivad fookusgrupid hariduslikke erivajadusi, eriti andekust ja andekat õppijat?

2. Millised on fookusgruppide arusaamad andekate õppest muutunud õpikäsituse kontekstis, milline on seisukohtade ühisosa ja missugune variatiivsus esineb nende arusaamades?

3. Kuivõrd agentsed on vastutavad sidusrühmad võimustruktuuride esindajatena?

Uurimisküsimustele vastamiseks kutsusime kokku viis fookusgruppi, kellega tegime rühmaintervjuud. Esimese uurimisküsimusega püüame selgitada fookusgruppide arusaamu nii laiemalt hariduslikest erivajadustest kui ka kitsamalt andekusest. Arusaamade ühisosa näitab, mis annab ühiskonnas tegelikule dialoogile alust, seevastu arusaamade variatiivsus selgitab üksikute fookusgruppide tõekspidamisi ja osutab, kas ühiskonnas ollakse valmis uue strateegiaga kaasa minema või väljendavad arusaamad pigem tõrjuvust. Hariduse osalejarühmade tegutsemisvalmidust hindame fookusgruppide agentsuse kaudu. Lisaks võimaldab uuring selgitada, kuidas fookusgruppide konstrueeritud diskursus suhestub eespool vahendatud teadusdiskursuses arenevate või teiste riikide praktikas levinud arusaamadega.

\section{Materjal ja metoodika}

\section{Valimi kirjeldus}

Uuringu valimiks on haridussüsteemi viie sidusrühma esindajatest moodustatud fookusgrupid (vt tabel 1). Ühelt poolt soodustab nende rühmade koostöö ja panus muutunud õpikäsituse rakendumist tervikuna. Teiselt poolt on uurimisprobleemi lahendamisel oluline igaühe individuaalne panus, mida toetab asjaolu, et kõigi fookusgruppide liikmete igapäevasesse vastutusalasse kuuluvad ka erivajadusega õppurite probleemid ja küsimused, millega neil tuleb tegelda. 
Tabel 1. Uuringus osalenud fookusgrupid ja nende ametialasest vastutusest tulenev seos uurimisobjektiga

\begin{tabular}{l|l|l}
\hline Fookusgrupp & $\begin{array}{l}\text { Fookusgrupi } \\
\text { sidusrühmad }\end{array}$ & $\begin{array}{l}\text { Fookusgrupi liikmete seos hariduslike } \\
\text { erivajadustega }\end{array}$ \\
\hline $\begin{array}{l}\text { Fookusgrupp 1 } \\
\text { (FG1) }\end{array}$ & $\begin{array}{l}\text { Õpetajakoolituse } \\
\text { teadlastest } \\
\text { õppejõud }\end{array}$ & $\begin{array}{l}\text { 1. Osalejate arusaam kujundab igapäevase } \\
\text { õpetamispraktika teoreetilist tausta } \\
\text { 2. Osalejad koolitavad õpetajaks õppijaid }\end{array}$ \\
\hline $\begin{array}{l}\text { Fookusgrupp 2 } \\
\text { (FG2) }\end{array}$ & $\begin{array}{l}\text { Hariduse tugi- } \\
\text { teenuste pakkujad }\end{array}$ & $\begin{array}{l}\text { Osalejate - SA Innove arenduskeskuste õppe- } \\
\text { nõustamis- ja karjääriteenuste spetsialistide - töö- } \\
\text { ülesanded on seotud HEV-õppe nõustamisega }\end{array}$ \\
\hline $\begin{array}{l}\text { Fookusgrupp 3 } \\
\text { (FG3) }\end{array}$ & $\begin{array}{l}\text { Kohalike oma- } \\
\text { valitsuste haridus- } \\
\text { ametnikud }\end{array}$ & $\begin{array}{l}\text { Osalejate ülesannete hulka kuulub haridusseaduse } \\
\text { järgi haridusjuhtide ja pedagoogide nõustamine }\end{array}$ \\
\hline $\begin{array}{l}\text { Fookusgrupp 4 } \\
\text { (FG4) }\end{array}$ & Koolijuhid & $\begin{array}{l}\text { Osalejad vastutavad otseselt HEV-õppe tingimuste } \\
\text { loomise ja probleemide lahendamise eest }\end{array}$ \\
\hline $\begin{array}{l}\text { Fookusgrupp 5 } \\
\text { (FG5) }\end{array}$ & Õpetajad & $\begin{array}{l}\text { Osalejate igapäevatöö on muu hulgas suunatud } \\
\text { HEV-õppijatele }\end{array}$ \\
\hline
\end{tabular}

Kõik fookusgrupid koosnesid viiest inimesest ja olid moodustatud ühtsel põhimõttel: igas grupis osales üks inimene, kes oli seotud uue haridusstrateegia elluviimiseks kokkukutsutud ümarlauaga ja kes omakorda kutsus fookusgrupi intervjuule neli sama sidusrühma kolleegi. Seega osales intervjuudes nii neid, kes olid kursis uue õpikäsituse ja sellest lähtuva õpilase individuaalse arengu toetamise ideega, kui ka neid, kes nendega tuttavad polnud. Uuringu kriitikana tuleb märkida, et kaasamata jäi kaks olulist haridussüsteemi sidusrühma - õpilased ja lapsevanemad -, paraku ei osalenud need rühmad ka eelnimetatud ümarlaual.

\section{Metoodiline raam}

Lähtusime uuringus sotsiaalse konstruktsionismi ${ }^{5}$ ideest, mille järgi tegelikkus on konstrueeritud ja toimib ühiskondlike uskumuste ja kokkulepete süsteemina, mida ühiskonda koos hoidvad eliidid jätkuvalt korrastavad või alal hoiavad (Berger \& Luckmann, 1966; Burr, 1995; Raud, 2013). Sotsiaalne konstruktsionism rakendab konstruktsionistliku paradigma suunana muu

\footnotetext{
Sotsiaalkonstruktsionistliku maailmakäsituse üks alustekste on Bergeri ja Luckmanni „The social construction of reality" (1966), milles kasutatakse terminit sotsiaalne konstruktivism. Samas on Gergen (1985) ja Burr (1995) märkinud, et tihti kasutatakse termineid konstruktivism ja konstruktsionism vaheldumisi ja rööpselt. Siinses artiklis eelistame viimast, sest konstruktivism viitab Gergeni (1985) sõnul liialt Piaget' teooriale või teistele tajuteooriatele ja tekitab segadust.
} 
hulgas sotsiaalkriitilisi meetodeid, nagu diskursuseanalüüs. Viimane on üks olulisimaid ja laialt kasutatavaid ühiskonnakäsitlusi; see ühendab endas nii teoreetilised mõttemudelid kui ka metodoloogilised suunised, lähtudes eeldusest, et keele abil konstrueeritud füüsiline ja mentaalne maailm omandab tähenduse diskursuse kaudu (Jorgensen \& Phillips, 2002, lk 15). Kriitilise diskursuseanalüüsi (CDA) vaateviisis jõustub iga ideoloogia, k.a hariduses valitsevate tõekspidamiste, suhtumiste, hoiakute ja käitumise süsteem, sümbolite, rituaalide, diskursuste või muude sotsiaalsete tavade kaudu (vt Dijk, 2005, lk 41-57).

CDA käsitused ja rakendusviisid eristuvad peamiselt maailmapildi konstrueerimisel ilmneva diskursuse rolli kaudu, aga ka analüütilise lähenemisviisi poolest (Jorgensen \& Phillips, 2002, lk 18). Erinevalt lähenemisviisidest, mis võrdsustavad teksti ja diskursuse, selgitamata, kuidas mõttemudeleid tekstist täpselt leida (Dijk, 2005, lk 231), defineerib sotsiolingvistiliste uurimustega tegelenud Norman Fairclough (2010, lk 59) diskursust sotsiaalse süsteemina, näidates täpselt, kuidas tekst seotakse võimu ja ideoloogiaga. Fairclough'i (1992) keskne idee on, et lingvistiliselt markeerituna taastoodab ja muudab diskursus teadmist, identiteete, sotsiaalseid suhteid, kujundades sotsiaalseid struktuure ja tavasid. Tema kolmeastmeline analüüsimudel võimaldab intervjueeritavate keelekasutuse sõna- ja lausetasandi analüüsilt liikuda kaugemale ja lahata ka tekstiosade suhteid, et jälgida, mis teemad tõstetakse esile ning mis jäävad tagaplaanile (ibid.).

Kriitilise tõlgenduse vaatenurgast on oluline, kuidas diskursiivsete tavade süsteem pakub võimalusi kindlas kontekstis luua ja taasluua tähenduskooslust - praegusel juhul alles juurduvat, kuid riiklikku (ja Euroopaga kooskõlas) strateegiat -, välistades alternatiivsed diskursused. Kui olemasolevatele dominantsetele suhetele osutatakse vastupanu ja suhtluskogukond on avatud võistlevate huvirühmade mitmese rõhuasetusega diskursusele praegusel juhul astuvad fookusgruppide hääled dialoogi - , siis toimubki kultuurimuutus. Kommunikatsioon toetub võimustruktuuride komplekssele süsteemile, mis pühendab ja positsioneerib inimesi kindlal viisil ning lubab viidata just fookusgruppide ja nende vastutus- ehk tegevusalale (Mumby, 1989). Seetõttu on uuringus vaatluse all osalejarühmade valmisolek muutuseks ning nende agentsuse analüüs.

Sidusrühmade suhtumist väljendavad modaalsed keelevahendid: aeg, kõneviis, eitus, retoorilised võtted. Nii lubab keelekasutuse analüüs selgitada, mis rollidesse asetab kõneleja enda ja selle, kellest ta räägib. Fairclough (2001, lk 92-93) pakub sõnavaraanalüüsi kui moodust vaadelda, milliseid kategoriseerimise viise ning ideoloogiliselt olulisi sõnavalikuid tekst sisaldab. Nii leitakse, milliste tunnuste kaudu kõneleja nähtusi kirjeldab (nt 
hea õppija või rühmas tunnustatud), milliste vastanduste kaudu ta osalejaid rühmitab (nt olümpiaadil edukas pole inimesena edukas) ja milliseid ühiskondlikke valikuid pakub (nt võitjad, kaotajad).

Tegevused eeldavad agente ehk kontrollivaid osalisi, kuid tegija võib olla tekstis varjatud või tagaplaanil (Leuween, 1996). Agentsuse grammatilisel eritlemisel jälgitakse, kas kõneleja kasutab aktiiv- või passiivlauseid (tegija on sõnaga nimetatud või ebaisikuline ja asjad toimuvad iseenesest), samuti kas laused on jaatavas või eitavas kõnes (Fairclough, 2001, lk 93). Nii näitab lausetasandi analüüs, kuidas kõneleja kujundab oma suhtlejarolle ja identiteeti, kuid ka seda, milliseid ühiskondlikke rolle pakub ta teistele osalistele. Näiteks võib selguda, kuidas konstrueeritakse andeka õppija rolli: kes saavad aktiivselt olukorda mõjutada ning kes peavad pakutud rolli passiivselt omaks võtma (nt neid saadetakse ja suunatakse). Meetod võimaldab selgitada, kuivõrd agentsed ja seega tegutsemisvalmid on protsessis vastutavad osalejarühmad ning kas nad näevad ka õppija aktiivset rolli ja kõikide poolte aktiivset koostööd õppija arengu toetamiseks, mida eeldab muutunud õpikäsitus.

\section{Uurimisprotsess ja andmeanalüüs}

Fookusgrupi intervjuud toimusid mõlema uurija juhatatuna vahemikus 14.04.-12.06.2015. Tavapäraselt on sellise intervjuu juhataja ülesanne pakkuda välja teemad, hoida diskussiooni fookust, innustada grupi liikmete vaba eneseväljendust ja julgustada esitama ka vastuolulisi seisukohti (Kvale, 2008, lk 74). Töö kahe uurijaga võimaldas juhatamise kõrval märgata võimalikult palju olulisi detaile ning esitada nendega seotud lisaküsimusi. Intervjuukava lähtus püstitatud uuringuprobleemist, sisaldades järgmisi küsimusi.

1. Kuidas mõistate uue õpikäsituse kontekstis hariduslikke erivajadusi?

2. Mida teie jaoks tähendab andekus ja kes on andekas õppija?

3. Mis seoseid andekus teie jaoks veel tekitab, millised mõisted sellega seoses esile kerkivad?

4. Milline erinevus võiks teie arvates olla andekate hariduses praeguse õpikäsituse ja muutunud ópikäsituse kontekstis? Kas ja kuidas te seda erinevust tajute?

5. Kuidas teie arvates tuleks muutunud õpikäsituse tingimustes tegeleda andekate õpetamisega? Kas andekust peaks märkama ja kes seda peaks tegema? Intervjuud (70-95 minutit) salvestati, litereeriti ja märgendati. Andmeanalüüs toimus kahes järgus, mille käigus otsisime arusaamade ühisosa ja variatiivsust nii fookusgruppide sees kui ka vahel. Esimeses, sisuanalüüsi jär- 
gus märgendasime sisukategooriad, nt HEVi või andekusega seostatud diskursused, neis esile tulnud rollid, tunnused ja protsessid. Diskursuste ja neisse kuuluvate sisuüksuste märgendamise käigus ilmnes ka see, kuidas kindlat sisu keeleliselt markeeritakse. Teises järgus viisime läbi kolm CDA etappi: analüüsisime keelevalikuid, tõlgendasime neid vahetus kontekstis ja otsisime sõnastusleidudele selgitusi ajastuomastest ideoloogilistest suundumustest.

\section{Tulemused}

Allpool näitame kõigepealt, mis kategooriate kaudu ja milliste nimetuste abil kirjeldasid fookusgrupid hariduslikke erivajadusi ja andekust. Seejärel tutvustame grupiintervjuudes eendunud diskursusi: esiteks neid, millega kõik uuritud grupid konstrueerivad muutunud õpikäsituse kontekstis arusaamasid andekate haridusest; teiseks neid, mis on omased kindlatele rühmadele. Diskursuste kirjelduste juures peatume ühtlasi sellel, millisena näitab keelekasutus sidusrühmade enda valmidust tegutseda muutunud õpikäsituse kohaselt.

CDA mudelit järgides (vt ülal) toome iga eendunud diskursuse puhul esile intervjueeritavate kasutatud keelelised valikud ja nende kontekstuaalsed tõlgendused, seejärel aga selgitame, milliseid tähendusi ja sotsiaalseid suhteid uuritud grupid intervjuudes konstrueerisid, st kuidas kujutasid protsessiosaliste (k.a enda) agentsust, muid suhtlejate rolle või identiteete.

\section{Sidusrühmade arusaamad hariduslikest erivajadustest (k.a andekus ja andekas õppija)}

Hariduslikke erivajadusi konstrueeriti kahel tasandil: laiemalt õppijate individuaalset eripära silmas pidades, kitsamalt ühele kindlale eripärale (puudele, käitumishäirele, andekusele) keskendudes ja HEV-õppijat selle alusel kirjeldades.

Ühelt poolt kirjeldasid intervjueeritavad hariduslikku erivajadust kui puuet (nt Kellel on seal mingid keskendumishäired või midagi sellist (FG5)); teisalt kirjeldati HEVina individuaalseid oskusi ja võimeid ning nende arendamine seoti sobivate õpimeetoditega. Toodi esile, et kõigil õppijatel on individuaalsed eripärad (nt õpistiil), millega tuleb õpiprotsessis arvestada (2-4) või mille põhjal õpiprotsessi muuta (1). HEV-nimetust tajuti kunstlikult loodud terminina (3, ka 2).

(1) Õppekava järgi on need lapsed, kelle erisusest tulenevalt tuleb teha kas ruumis või õppekavades mingisuguseid muudatusi. (FG1) 
(2) Ma ütlen, et meil kõigil on hariduslikud erivajadused. (FG1)

(3) Kohati tundub väga kunstlik see HEVi tekitamine. [...] Need hästi andekad on üks asi, aga me võime öelda, et HEV-vajadus on ka inimese õpistiil. (FG2)

(4) Meie individuaalsus on see hariduslik erivajadus, mis hakkab tingima seda, kuidas, kus, milliste meetoditega me kõige paremini õpime. (FG1)

Diskursustest eristus HEVi kirjeldavana kaasava kooli diskursus, mida konstrueeriti sõnade kohanemine ja kaasamine kaudu. Osalejad kasutasid umbisikulisi passiivlausete konstruktsioone (kool peab kohandama, koolisüsteem peab võimaldama), tegeliku vastutajana kedagi konkreetset ei nimetatud (5).

(5) Kool peab kohandama materjale ja see ei ole ainult see, et igal erivajadusega lapsel peab kaasas olema oma tugiisik või assistent, vaid ikkagi koolisüsteem peaks võimaldama sellel lapsel õppida võimalikult palju koos teistega. (FG1)

Kaasava kooli diskursusega vastuolus oli eristumise-eristamise diskursus, mida kirjeldati väikeklassi või erikooli võtmes (6). HEV-laste üleviimist tavaklassi nimetati tasandamiseks, mis aeglustab ülejäänute õpitempot (6).

(6) Tegelikult see on õige, et need lapsed on väikeklassis. Siis peale neljandat klassi neid tasandatakse ja ma näen, et see tõmbab klassis terve tempo alla. (FG5)

Intervjuude põhjal eristusid selgelt andekus ja muud hariduslikud erivajadused (nt 7). Vastajad kirjeldasid HEV-õppijaid kui kohustust, kellega kool peab tegelema (5) ning kelle tõttu kõik kannatavad (6: tõmbab klassis terve tempo alla). Ka andekaid nähti takistusena: nad segavad õppetööd ja võtavad ressursse ning neist on kerge mööda minna (6-10).

(7) Kui on lapsel mingi puue, siis kool peab midagi konkreetselt tegema. Aga see õpilane, kes ongi kas õpistiilidelt või andekuselt või mingitelt huvidelt või oma temperamendilt teistsuguste vajadustega, temast on kerge mööda minna. (FG2)

(8) Kui on raske HEV-õpilane klassis, siis paratamatult ühel või teisel moel kannatavad kõik teised. (FG4)

(9) Me ainult diagnoosime ja sildistame, teeme raviplaane, justkui 21. sajandi õpilane oleks tõesti mingisugune defektne, keda peab kogu aeg lappima ja parandama. (FG4) 
(10) ... meid ikkagi kannustavad taga mingisugused tulemused või mingid eksamid ja õpetajal lasub mingi kohutav vastutus. (FG2)

Teemast rääkides kasutati meie-vormi (diagnoosime, teeme, sildistame), agendina tegutses kool, kes peab teatud asju tegema. Hariduslikke erivajadusi kirjeldati erinemise diskursuse kaudu, rõhutades, et sageli on HEV-õppija koolis üksik ja sõpradeta ( $k$ ui sa natuke erined, ei tule rühmatööst midagi välja, sest keegi ei taha sind kampa (FG2)).

Andekust ja andekaid õppijaid nimetati eri viisidel, mis on fookusgrupiti esitatud tabelis 2 . Tabel ilmestab, kuidas sidusrühmad andekust nimetavad, milliste vastanduste kaudu nähtust rühmitavad ning milliseid ühiskondlikke valikuid pakuvad.

Eeltoodust nähtub, et haridusliku erivajadusena sõnastasid andekuse vaid kahe fookusgrupi liikmed: koolijuhid ja õpetajad (nt Erivajadus on ta [andekus] ainuüksi juba selle pärast, et on vaja eriliselt täiendavat hoolt kanda, pöorrata tähelepanu (FG4)). Andekust kirjeldati superlatiivse sisuga keelekonstruktsioonide kaudu, nt superman, Eesti insener. Positiivset suhtumist esindasid intervjuudes nimetused geenius, oivik, sädelaps, tubli, tark.

Mitmed pakutud nimetustest viitasid erinemisele normaalsest: häda küljes, liiga tark, kõrvalekaldega, ettearenenud, probleemne, tõrjutud. Andekat konstrueeriti negatiivsete nimisõnade (tuupur, vatitupsulaps, pugeja) ja omadussõnade abil (õnnetu, tasakaalutu, jõle tüütu) ning kirjeldati abivajajana: kriisis olev laps, ei suuda elus oma kohta leida. Enamasti nähti andekust kaasaantud või -sündinud isikuomadusena (tark, nutikas, võimekas, taiplik, loomult laia silmaringiga). Vähem väljendati andekust tegevuse (nt ta ópib ebatraditsionaalses oppistiilis, on motiveeritud, out of the boxmõtleja) ja tegevuslaadi kaudu (tubli, usin, agar, loov) ning nimetati tegevustes pakutavat tuge (ópetaja töö vili).

Kokkuvõttes võib öelda, et andekate identiteete kujundatakse eelkõige sotsiaalse staatuse ja kuuluvuse alusel (nohik, tõrjutu, pugeja), võrdluses teiste klassi liikmetega (klassi priimus, liider, oivik), sh tihti ka madalama positsiooni kaudu (tõrjutud, nohikud, pugejad, ei suuda elus oma kohta leida). Rollid, mida andekatele pakutakse, on ühiskondlike hierarhiate äärmustes: ühelt poolt geeniused, superman'id, tipud, teiselt poolt tõrjutud, nohikud, pugejad või need, kellel on häda küljes. Oluliselt vähem konstrueeritakse andekuse tähendust individuaalse eneseteostuse kontekstis (ennastjuhtiv, motiveeritud) ning õpitegevuste kaudu (usin, agar, õpib ebatraditsionaalses õpistiilis). 


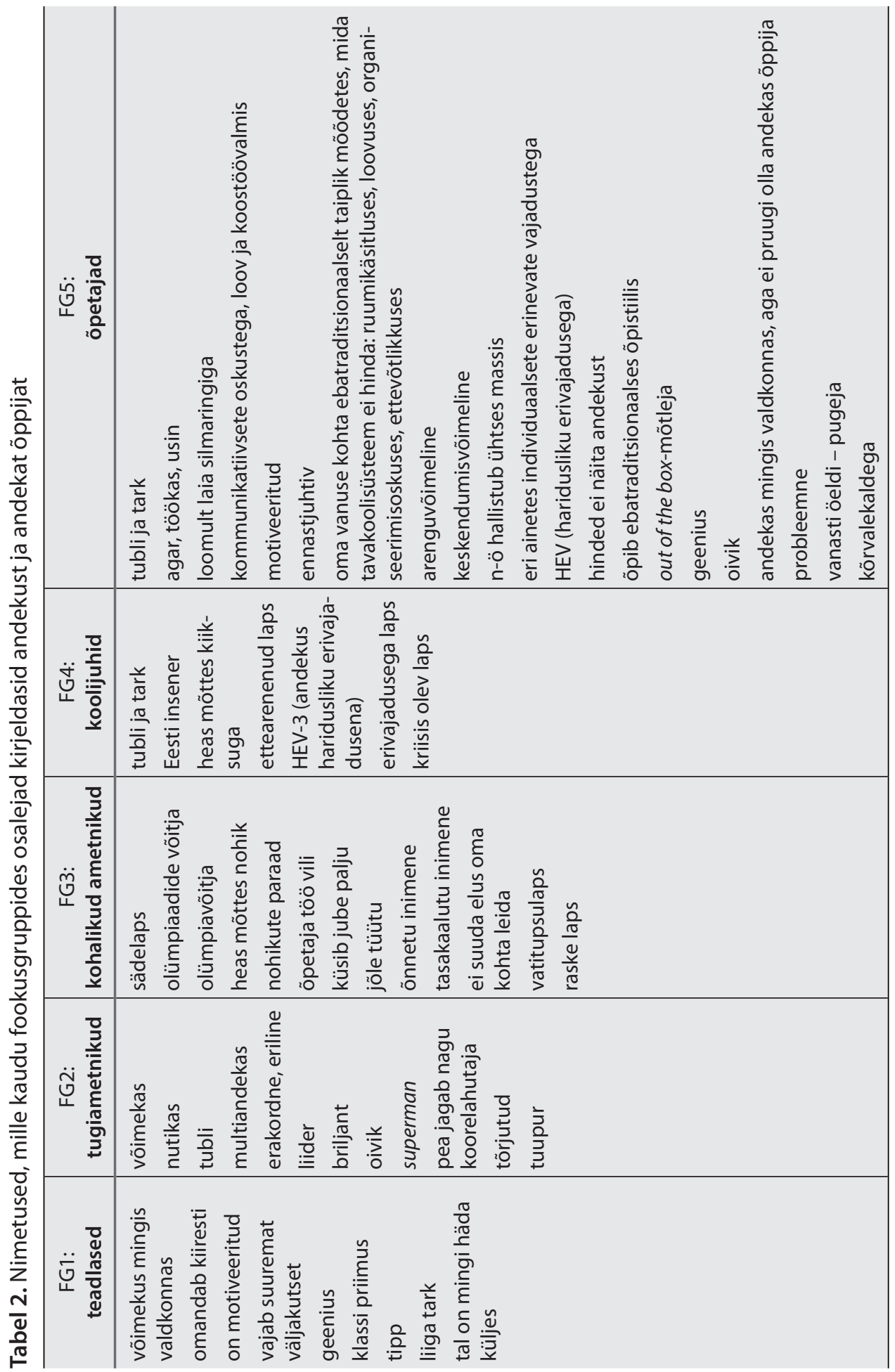




\section{Sidusrühmade arusaamad andekate haridusest ja tegutsemisvalmidus muutunud õpikäsituse kontekstis}

\section{Sidusrühmade ühised arusaamad andekatest koolis}

Sidusrühmade ühiste arusaamadena eendusid diskursused, mis peegeldavad andekaid kui õppijaid, 1) kes on ühiskonnale olulised, kuid kelle annete arendamisele tähelepanu ei pöörata (andekad-jäävad-tagaplaanile diskursus); 2) keda saadetakse erinevatele võistlustele (olümpiaadidele saatmise diskursus) ja 3) kelle võimeid ja vajadusi arvestava õppe jaoks ei jätku aega ega raha (puuduvate ressursside diskursus).

Andekad-jäävad-tagaplaanile diskursuses kirjeldati andekat õpiprotsessis, suhestades teda teiste õppijatega tipu või järjekorra lõpu ning Harju keskmise jt metafooride kaudu. Umbisikuliselt sõnastati, et andekad on need, kellega koolis ei tegeleta (7: temast on kerge mööda minna) ning kes manduvad. Andekust vastandati teistele hariduslikele erivajadustele, nimetades kõiki ülejäänuid keerulisteks ja rõhutades kohustust kindla kõneviisiga (7: kool peab midagi konkreetselt tegema).

Vastajad rääkisid andekatest umbisikuliselt (11: jäävad pigem tähelepanuta, 7: temast on kerge mööda minna), v.a taunitava käitumise puhul olukorras, kus nad muutuvad agentideks (14: ta hakkabki tundi segama, ... mandub, 15: ta vajub mugavustsooni).

(11) Eesti kool paistab sellega silma, et just need andekad jäävad pigem tähelepanuta, et rohkem pöörame nendele, kellel ei ole seda andekust, n-ö keerulistele. (FG1)

(12) Andekas on jäänud järjekorra lõppu, kahjuks. (FG4)

(13) Tipud jäävad tähelepanuta ja n-ö hallistuvad ühtses massis. (FG5)

(14) Kui tal [andekal] on igav, siis ta hakkabki tundi segama, ta nõuab tähelepanu ja lõpuks mandub selle harju keskmise peale. (FG4)

(15) Andekas õpilane on tihtipeale silmitsi sellega, et kuna tal võib minna tunnis igavaks, siis ta vajub mugavustsooni ja laiskuse kütkeisse. (FG5)

Õppijaid kirjeldati skaalal, kus on nõrgemad, keskmised ja tugevamad. Vastaja osutas umbisikuliselt, et nõrgemaid püütakse ... keskmiste poole tõmmata (16), kus tõmbamise metafoor objektistab õppija. Meie-vormi (me räägime) kasutades vähendas kõneleja enda vastutust, seejuures paikneb andekas tema jaoks sotsiaalses hierarhias kõrgel kohal ning hakkab kaasama teisi - selle verbi kasutamine koos tulemusliku määrusega lõpuks viitab muutunud õpikäsitusele tulevikus. 
(16) ... nõrgemaid püütakse enam-vähem sinna keskmiste poole tõmmata, mis on väga positiivne nende nõrgemate jaoks, aga kui me räägime ühiskonna jaoks laiemalt, siis andekuse märkamine, andeka lapse suunamine-arendamine on ju ühiskonna jaoks tohutu väärtus, sest see on see, kes lõpuks viib ühiskonda edasi ja kes omakorda oma andekusega hakkab kaasama teisi. (FG1)

Olümpiaadidele saatmise diskursuses rägiti andekate haridusest konkurentsi kontekstis: olümpiaadidest ja võistlustest, kuhu neid umbisikulist tegumoodi kasutades saadetakse (19) ja kus nad saavad annet välja elada (17). Näide 19 mõjub umbisikulise metafoori tükkideks tõmbama tõttu halvustavalt ja liialduse (viiel erineval olümpiaadil) tõttu irooniliselt. Ka selles diskursuses kujutatakse andekat ebaõnnestujana (18: nüüd olen tegelikult töötu). Vastaja konstrueerib teie-meie vastanduse: teie (olümpiaadide korraldajad) tunnustate, meie (andekad) oleme tublid, aga potentsiaalsed töötud.

(17) ... kõikvõimalikud võistlused, seal said nad [andekad] oma annet siis välja elada. (FG2)

(18) Üks olümpiaadi lõpetaja kunagi ütles, et te tunnustate siin meid, et me oleme tublid, me oleme targad, aga mis me sellega peale hakkame? Ma läksin ülikooli, õppisin, sain doktoriks, nüüd olen tegelikult töötu. (FG3)

(19) Kui kedagi on vaja olümpiaadile saata, siis näidataksegi ühe lapse peale, sest eeldatakse, et tema on kõiges andekas. [...] Need, kes on andekad, need tõmmatakse tükkideks sellepärast, et nad käivad viiel erineval olümpiaadil. (FG5)

Puuduvate ressursside diskursuses tõstatus omaette teemana andekate õpetamiseks puuduvad vahendid, nt aeg, raha. Diskursust konstrueeriti eituse kaudu, agendi vm subjektina esinesid õppijate kõrval õpetajad (20: õpetaja üldse ei suhtle, 22: õpetajatel ei ole fü̈̈siliselt aega). Kui muutunud õpikäsituse kohaselt on õppimine individualiseeritud, siis seda vastajate tõekspidamised ei toetanud, sest nende hinnangul andekate üks ühele õpetamine võtab ära ressursse teistelt õppijatelt.

(20) Talle antakse mingisugused oma töölehed kätte, aga temaga õpetaja üldse ei suhtle, sest tal pole aega. (FG1)

(21) ... selle haridusliku erivajaduse eest peab ju [riik] eraldi maksma. (FG3) 
(22) Kust leida see raha, et ma tahan teha individuaalset tööd üks ühele andekaga? [...] Õpetajatel ei ole füüsiliselt aega, et nad saaksid sellele väga olulisele andekusele tähelepanu pöörata. (FG4)

Sidusrühmade ühiste arusaamade kohaselt jäävad andekad haridussüsteemis tagaplaanile, nad segavad óppetööd, vajavad lisaressursse. Samas hoitakse ja parandatakse nende kaudu kooli mainet (osalus olümpiaadidel).

\section{Sidusrühmade erinevad arusaamad andekatest koolis}

Variatiivsus ilmnes nende diskursuste puhul, mis tõstatusid ainult üksikute fookusgruppide intervjuudes, kuid puudusid teistes. Eristavate diskursuste kaudu tulid esile fookusgrupid, kes on uue õpikäsituse kasutamiseks valmis, ja need, kes käsitlevad andekust vana, kuid osati veel käibiva õpetajakeskse õpikäsituse võtmes.

Haridusteadlaste (FG1) kirjeldustes seondus andekate haridusega oodatavalt teadusdiskursus. Nii teadlased kui ka õpetajad (FG1, FG5) seostasid andekaid koolis ennastjuhtiva õppija diskursusega. Kolmandana eristus vaid haridusametnikele (FG3) omasena tavakooli õigustamise diskursus, mida otseselt vastandati teadlaste positiivselt esiletoodud alternatiivõppe diskursusele. Sotsiaalse kihistumise diskursus esines nii maa ja linna vastandamisena (tugiteenuste pakkujad ja ametnikud ehk FG2 ja FG3) kui ka eesti- ja venekeelsete õppijate vastandamisena (koolijuhid ehk FG4). Õpetajate (FG5) intervjuu erines teistest muutunud õpikäsitust enim toetavate kirjelduste poolest, mis avaldusid eelkõige õppijale vastutuse andmise diskursuses.

Teadusdiskursuses rõhutati õpilaste pideva uurimise ja jälgimise vajalikkust. Erivajadusi, sh andekust, nähti millenagi, mida potentsiaalselt võiks ja tuleks objektiivselt mõõta ja jälgida (23-24), kuid mida ei tehta (24: meil ... ei kasutata, 25: me tegelikult ei uuri üldse ...). Diskursust iseloomustab teadusleksika, nt diagnoosimine, testid, monitooring, seire ja uurimine kui protsessid, kus ekspert on õpetaja või õppejõud. Agendina nimetati meid $(23,25)$, mis viitab osalejat kaasavale kollektiivsele vastutusele, kuid vastutus on kohati ebamääraselt instrumentaalne ja tingivas kõneviisis ka irreaalne (24: vahendid võimaldaksid .. meil 'Eestis').

(23) Me võiksime n-ö diagnoosida vähemalt korra aastas kõik lapsed läbi. (FG1)

(24) Tänapäeva vahendid võimaldaksid lapse arengu ja eripära jooksvat monitooringut, aga meil seda praktiliselt üldse ei kasutata. (FG1) 
(25) Me tegelikult ei uuri üldse seda, millised meie lapsed on, nii et minu jaoks kogu selle uue õpikäsitluse üheks taustaks on pigem monitooring või seire lapse arengu ja vajaduste üle, mitte ainult õpetaja üle. (FG1)

Teadusdiskursuse raames ilmnes ka seoseid andekusteooriatega (26). Andekus seoti ühelt poolt kindla valdkonnaga (milles nad on kõige tugevamad), mida saab - v.a sünnipärasuse osas - seostada Gardineri kognitiivsete andelaadimoodulitega, ning teiselt poolt sünnipäraste võimetega (andekad looduse poolt) ja arengu kognitiivsete või sotsiaalsete aspektidega (andekad .. elu kulgemise poolt), nagu on omane pigem andekuse arengulistele mudelitele (nt Gagné mudel). Erandlikult kasutab vastaja mina-vormi, esitades oma seisukoha arvamusena (minule meeldib).

(26) Minule meeldib väga see Howard Gardneri multiintelligentsuse süsteem [...], mis võimaldaks lastel õppida läbi selle, milles nad on kõige tugevamad, tõmmata järel neid valdkondi, milles nad on vähem andekad looduse poolt või elu kulgemise poolt. (FG1)

Ennastjuhtiva õppija diskursuses kirjeldati andekaid kui õppijaid, kes on võimelised ise õppima ja arenema (28), kuid kes on liiga tarkadena sotsiaalselt klassiruumist välja arvatud. Õpetaja paigutati eksperdi rolli, kes suudab eristada andekat nendest, kellel erilisi arenguvajadusi ei ole (28), ja toetab tema initsiatiivi õppida (27: sina ... võtad seal mingi materjali ja tema saab oma võimete kohaselt õppida). Kõneleja kirjeldab õpetajat üldisikulises sinavormis, kasutades meie-vormi ütleme 'näiteks'.

... sina lähed õpikeskusesse, võtad seal mingi materjali ja tema saab oma võimete kohaselt areneda, sealsamas kui õpetaja töötab teistega, kellel ütleme neid erilisi arenguvajadusi ei ole. (FG1)

(28) Tema saab hakkama nagunii, tema saab hakkama ise. (FG1)

Alternatiivõppe diskursus tõstatus õpetajakoolituse teadlastest õppejõudude vestluses (29): adjektiivi korralik kasutati eraharidusest ja alternatiivõppest rääkides ja selle olemasolu meil (Eestis) eitades, kuid samas tehti siiski mööndusi, nagu peaaegu ja tohutult vähe. Õppija objektistatakse (lapse ettevalmistamine), mis ei vasta muutunud õpikäsituse põhimõtetele. Alternatiivõpe erakoolis on teadlaste haridusideaal, mis Eestis pole võimalik (mida meil ... ei olegi, ei ole üldse, ei ole kusagilt häid kogemusi võtta). Teadlastest õppejõud võtavad siin sõna pigem eksperdina, mitte muutuste agendina. 
(29) Korralik lapse ettevalmistamine kooliks ja eluks, nagu seda teeb Montessori lasteaed, mida meil kahjuks peaaegu ei olegi. Montessori klasse meil ei ole üldse. [...] Eesti on tohutult vaene alternatiivsete pedagoogiliste süsteemide poolest ja see vaesestab meid. Meil ei ole kusagilt häid kogemusi võtta. (FG1)

Tavakooli õigustamise diskursuse kaudu väljendasid omavalitsusametnikud (FG3) muret, et tavakoolid ei vasta ühiskonna ootustele. Samas tajuti erakoole, milles haridusteadlased nägid potentsiaali (vt 29), probleemi ja ohuna. Erakoolist rääkides (30) kasutas üks ametnik emotsionaalselt laetud tavatuid metafoore (tavakool kui põrgu, kaabakad, erakool kui lillepidu), asetades end irooniliselt erakoolide positsioonile, kuid pannes samas nende vaateviisi küsimärgi alla ( $k a s$...). Omavalitsusametnike vastutavale agentsusele intervjuud ei osuta.

(30) Erakoolide üks eesmärkidest on hoida sellest ilgest maailmast eemale, et see tavakool on nagu põrgu ja õpetajad on kaabakad ja seal [erakoolis] on kõik lillepidu, ja kui kool nüüd läbi saab, siis kas ühiskond on neile olemas, kus on võimalik niimoodi edasi elada. (FG3)

Sotsiaalse kihistumise diskursus tõstatus nii hariduse tugiteenuste pakkujate ja omavalitsusametnike (FG2, FG3) kui ka koolijuhtide (FG4) intervjuudes. Ametnikel (FG2, FG3) olid fookuses andekate maalaste eneseteostuse vajadused ja piiratud võimalused. Vastandati Missot ja Tallinna. Vastajate hinnangul ei saa andekat väikekoolides toetada, diskursuses domineeris eitus. Arutlused on kirjeldavat laadi ega viita ühelegi agentsele vastutajale.

(31) Kumb see targem on, kas klass vahele jätta või kooli vahetada? Ega see ei ole lihtne ka lapsele selgeks teha, et vaheta neid klasse lihtsalt. (FG2)

(32) Suures keskuses nagu Tallinn on võimalik, aga kui me läheme kuhugi Missosse või väiksemasse kohta, siis see ilmselt niisama lihtne pole. (FG2)

(33) Samasugune sotsiaalne probleem on maapiirkonnas andekas. Sel vanemal, kes käib põllul või laudas tööl või seal kohalikus poes, saab oma 300 eurot palka, tal on andekas õpilane, tal ei ole raha, et igal hommikul saata see laps bussiga suurlinna keskustesse. (FG3)

Koolijuhid (FG4) seostasid kihistumisdiskursuse venekeelsete koolidega, näitena toodi teaduskoolide eestikeelsus, mis ei toeta andekate venekeelsete õpilaste arengut (34). Tegijat-vastutajat taas ei nimetata, vaid väljendutakse umbisikuliselt (et teda tunnustada, ... tuleb ta ... suunata). 
(34) Et teda tunnustada, julgustada, suunata, eriti veel venekeelses koolis, kus ta tuleb teaduskooli suunata, kus hakkab õppetöö ka kõik eesti keeles. Vene koolis on veel see samm ka, et see eesti keele oskus peab, sest riigieksamid on meil ka vene keeles, aga olümpiaadid, vabariiklikud, on enamuses eesti keeles. (FG4)

Õpetajatel (FG5) tõusis esile muutunud õpikäsituse seisukohti toetav õppijale vastutuse andmise diskursus, mille raames kirjeldati andekust kõige mitmekülgsemana (vt ka tabel 2), ühistegevuste, koosõppimise kaudu (35). Õppija on aktiivses rollis (saab katsetada, arendaks) ja saab sotsiaalseid oskusi arendada õpetaja loodud tingimustes (rühma õpetamine, väljakutsete esitamine), st vastutus on fookusgrupil endal, ehkki seda ei sõnastata.

(35) Võib-olla see vastutuse andmine õpilasele, et tema on see, kes andekana saab katsetada rohkem ka seda rühma õpetamist ja-ja ... ja selliseid uusi ... ja võib-olla selles mõttes väljakutsete esitamine sellele andekale, et tema areneks ja arendaks ka oma teisi oskusi. (FG5)

Kokkuvõttes võib väita, et kui võtta fookusesse sidusrühmade erinevad arusaamad andekatest koolis, siis domineerivad diskursused, mis pigem soodustavad muutunud õpikäsituse rakendumist. Fookusgrupid ennast samas agendina ei näe - ainus erand on õpetajate rühm, kelle vastutus õpikeskkonna loojana implitseeritakse klassitööst kõnelemise kaudu.

\section{Järeldused ja arutelu}

Andekus on haridusliku erivajadusena Eestis küll riiklikul tasandil sõnastatud (Põhikooli- ja gümnaasiumiseadus, 2010), kuid uurimuses ilmnenud tõekspidamiste järgi seostuvad hariduslikud erivajadused Eestis siiski eelkõige puuete ja õpiraskustega (eristumise ja andekad-jäävad-tagaplaanile diskursus), mis kinnitab Norwichi ja Eatoni (2015) sellekohast oletust. Otseselt seostasid andekust haridusliku erivajadusega vaid koolijuhtide ja õpetajate fookusgrupid (vt tabel 2), teadlastele ja tugiametnikele seostusid hariduslikud erivajadused kunstlikult loodud terminiga, mille alusel õppijaid eristada.

Sõnavaraanalüüs kinnitab, et hariduslike erivajaduste diskursus, nagu ka haridusdiskursus üldiselt (Bernstein, 1996), peegeldab, kinnistab ja kujundab sotsiaalseid identiteete. Murettekitav on olukord, et hariduse eest vastutajad paigutavad andekad õpilased stereotüüpselt sotsiaalses hierarhias kord tippu, kord kõige madalamale positsioonile (geeniusest nohiku ja tõrjutuni). 
Andekate tähistamiseks kasutatud nimetused (vt tabel 2) lubavad järeldada, et andekust tuvastatakse Eestis ebasüsteemse sildistamise kaudu, nagu rõhutatakse ka andekust sotsiaalse konstruktina käsitlevates uurimustes (nt Borland, 1997, 2005; Cigman, 2006). Freemani (2011) väide, et andekuse määratlemine sõltub olulisel määral õpetaja hoiakutest ja subjektiivsetest arusaamadest, milline peaks andekas õppija olema, leiab uuringu tulemusena kinnitust - just õpetajate fookusgrupi keelekasutuses esines palju positiivseid ja definitsioonidega haakuvaid jooni. Samuti toetab õpetajate vastustest ilmnenud andekale vastutuse andmise diskursus Claytoni (2015) väidet, et õpetaja vastutab andekate arendamise eest, ning oletust, et individuaalne töö andekatega muutub loomulikuks, nagu muutunud õpikäsitus seda eeldab.

Andekate nimetusi (vt tabel 2) andekusteooriate terminitega kõrvutades nähtub, et enamikus fookusgruppidest ei tule esile teoreetiliselt eeldatud andekustunnused: suured võimed, motivatsioon, elutarkus, intelligentsus, loovus (Renzulli, 1978; Sternberg, 2005). Loovust, erilist mõtlemist, agarust, motivatsiooni jms nimetasid üheskoos ainult õpetajad. Tugiteenuste ametnikud osutasid üksnes võimekusele, teadlased võimekusele ja motivatsioonile. Kõnekas on seegi, et ehkki õpilase annete mõõtmise ja seire vajadusest räägitakse, ei kasutata kordagi võimekuse mõõtmises enim levinud psühholoogiaterminit - intelligentsust. Õpetajad kasutavad selle sünonüüme taiplikkus ja tarkus. Kordagi ei esinenud intervjuudes keelendit talent. Ühelt poolt viitab see intervjuu küsimuste leksikavaliku peegeldamisele, teiselt poolt aga termini puudumisele eesti haridusretoorikas - sõna talent on küll kasutusel meedia andekusdiskursuses, kuid rõhutab ka seal eelkõige reklaami ja konkurentsi (Põlda, 2015).

Andekaid kirjeldatakse ainult üksikjuhtudel nende enda või kellegi teise tegevuste kaudu. Peaasjalikult vaid haridusinimesed käsitasid andekust sünnipäraste isikuomadustena. Sellest võib järeldada, et andekust ei mõtestata Eestis arengulistest aspektidest lähtudes (vrd Gagné, 2004).

Kuigi Eesti hariduspoliitika üks peamisi põhimõtteid on kõigi õpilaste arendamine vastavalt nende võimetele, hariduslike erivajaduste märkamine ja nendega arvestamine, kajastab gruppide seisukohtade ühisosa intervjuudes, et hariduslikke erivajadusi märgatakse, aga andekatega tegelemiseks pole piisavalt ressursse: nii andekad-jäävad-tagaplaanile kui ka puuduvate ressursside diskursus viitavad, et olud säilitavad status quo'd ega soodusta õpikäsituse muutust. Ohu märk on, et omavalitsusametnikud väljendavad traditsioonilise kooli eelistust otsesõnu.

Ühisel meelel ollakse selles, et andekad on kooli silt - nende väljund on olümpiaadid, kuhu tuleb kedagi saata. Seega toetavad siinse uuringu 
tulemused leidu, et meie haridustegelikkuses ei julgustata õpilasi saavutama kogu oma potentsiaali (Kitsing et al., 2015), ja PISA kvantitatiivseid mõõtmisi, mille kohaselt tegeletakse keskmiste õppijatega, kuid tipud jäävad tähelepanuta: Eesti haridussüsteem ei toeta andekate arengut klassiruumis (PISA, 2012; Säälik, 2012).

Andekusuurijate väide (nt Strand, 2006), et praktikas rakendatakse koolides enamasti Gardneri andelaaditeooriat, leidis kinnitust osaliselt. Ainus teooria, millele fookusgrupid viitasid, oligi Gardneri teooria: seda mainisid haridusteadlased, kes küll tõid esile vajaduse märgata individuaalset eriandekust, kuid samas sidusid andelaade Gardnerile võõralt sünnipäraste eelduste, mitte tegevustega. Võimekusvaldkondi (vt Saul et al., 2007) käsitleti enamasti üldiste intellektuaalsete võimetena, üksnes õpetajad sõnastasid individuaalseid andevaldkondi (ruumikäsitlus, loovus, organiseerimisoskus, ettevõtlikkus). Andekate õpetamist ei kirjeldatud individuaalõppe ega diferentseerimise abil (Laine \& Tirri, 2015). Seega näitab uuring, et õppijate individuaalsed erinevused või andevaldkonnad võivad tänu õpetajale koolis esile tulla, kuid individuaalse andekuse arendamise süsteemi loomiseks peaksid sellekohased arusaamad olema ka muudel fookusgruppidel.

Sidusrühmade esindajad kirjeldasid olukorda sageli eksperdi-teadja positsioonilt, nähes vajadust õpilase võimeid ja arengut mõõta ja seirata. Ühelt poolt ei määratlenud vastajad ennast enamikus situatsioonides agentidena - muutuvas õpiolukorras on kontrollivad osalised abstraktne kool, õpetajad, andekad ise. Kooli kontekstis kirjeldasid hariduse eest vastutajad tööd andekatega umbisikuliselt, andekaid nähti eraldatud rühmana. Teiselt poolt muudetakse andekas õpilane sõnades tegevuse objektiks (tuleb tunnustada, julgustada, suunata või andekale vastutuse andmine). Seega ei väljenda osalejarühmad ennast selgelt tegutsejate-vastutajatena, nagu kirjeldab Strand (2006) Gardneri teooria potentsiaali. Siiski tõuseb aeg-ajalt esile kõnelejat kaasav kollektiivne vastutus (meie-vorm), kuid see meie on enamasti nii avar, et tundub tähendavat Eestit.

Kokkuvõttes näitab uuring vastutavate osalejarühmade teadlikkust andekate erivajadustest ja samas distantseerumist probleemist. Nimelt ei väljenda sidusrühmade esindajate keelekasutus nende enda agentsust haridusmuutuste protsessis: nad ei kirjelda end tegutsejate-vastutajatena. Samuti toetab uuring järeldust, et andekate õppest rääkides ei kajastu hariduse sidusrühmade arusaamades ja keelekasutuses õppijakeskne muutuv õpikäsitus ning valdavalt domineerib traditsiooniline õpetajakeskne lähenemisviis (Jõgi et al., 2015; Loogma, 2014; TALIS, 2008). Siiski nägid uuringus osalenud õpetajad andekas õppijas suurimat potentsiaali, 
kirjeldades andekust ning andekat õppijat kõige mitmekülgsemalt. Eeldused muutunud õpikäsituse juurdumiseks on aga olemas: igal uuritud vastutajarühmal ilmneb mingi teistel puuduv või ühe-kahe rühmaga haakuv diskursus, mis näitab valmisolekut suunamuutuseks, toetades muutunud õpikäsituse rakendumist tingimusel, et need diskursused suudetakse viia dialoogi (vt kultuurimuutuse eelduste kohta Mumby, 1989). Seetõttu on ühiskonnas oluline tagada hariduse sidusrühmade vaheline koostöö ja rakendada muutunud õpikäsitust, et kõikide õppijate, ka andekate individuaalset arengut parimal viisil toetada. Planeeritud uuringud samas valdkonnas on seotud siinsest kõrvalejäänud sidusrühmade - laste ja lapsevanemate - kogemuste ja arusaamade uurimisega, loomaks ühist tähendust, seda mitte ainult vastutavate osalejarühmade, vaid kõikide sidusrühmade vahel.

\section{Tänuavaldus}

Artikli autorid tänavad fookusgruppides osalenuid sisukate intervjuude ja pühendatud aja eest ning professor Krista Kerget heade nõuannete eest.

\section{Kasutatud kirjandus}

Apple, M. W. (1996). Power, meaning and identity: Critical sociology of education in the United States. British Journal of Sociology of Education, 17(2), 125-144. doi: http://dx.doi.org/10.1080/0142569960170201

Berger, P. L., \& Luckmann, T. (1966). The social construction of reality: A treatise in the sociology of knowledge. New York: Anchor Books.

Bernstein, B. (1996). Pedagogy, symbolic control and identity: Theory, research, critique. London, Bristol: Taylor \& Francis.

Borland, J. (1997). The construct of giftedness. Peabody Journal of Education, 72(3-4), 6-20. doi: http://dx.doi.org/10.1080/0161956X.1997.9681863

Borland, J. (2005). Gifted education without gifted children: The case for no conception of giftedness. In R. Sternberg \& J. Davidson (Eds.), Conception of giftedness (2nd ed., pp. 1-19). Cambridge etc.: Cambridge University Press.

Burr, V. (1995). An introduction to social constructionism. London: Sage.

Casey, R., \& Koshy, V. (2013). Gifted and talented education: The English policy highway at a crossroads? Journal for the Education of the Gifted, 36(1), 44-65. doi: http://dx.doi.org/10.1177/0162353212469745

Cigman, R. (2006). The gifted child: A conceptual enquiry. Oxford Review of Education, 32(2), 197-212. doi: http://dx.doi.org/10.1080/03054980600645388

Clayton, N. (2015). How am I using my own understanding and development of gifts and talents to promote the learning of children? Gifted Education International, 32(1), 26-38. doi: http://dx.doi.org/10.1177/0261429415575123 
Eesti elukestva õppe strateegia 2020 (2014). Külastatud aadressil https://www.hm.ee/sites/default/files/strateegia2020.pdf.

Fairclough, N. (1992). Discourse and social change. Cambridge: Polity Press.

Fairclough, N. (2001). Language and power (2nd ed.). New York: Longman.

Fairclough, N. (2010). Critical discourse analysis: The critical study of language (2nd ed.). Harlow: Longman.

Fischer, C., \& Müller, K. (2014). Gifted education and talent support in Germany. CEPS Journal, 4(3), 31-54.

Freeman, J. (2006). Giftedness in the long term. Journal for the Education of the Gifted, 29(4), 384-403.

Freeman, J. (2011). What the World does for the gifted and talented. Paper presented at the Hungarian EU Presidential Conference on Talent Support, 7-9 April, Budapest.

Gagné, F. (2004). Transforming gifts into talents: The DMGT as a developmental theory. High Ability Studies, 15(2), 119-147.

doi: http://dx.doi.org/10.1080/1359813042000314682

Galton, F. (1869). Hereditary genius. [Digital version]. Retrieved from http://www.mugu.com/galton/books/hereditary-genius/.

Gardner, H. (1993). Frames of mind: The theory of multiple intelligences (2nd ed.). London: Fontana Press.

Gergen, K. J. (1985). The social constructionist movement in modern psychology. American Psychologist, 40(3), 266-275. doi: http://dx.doi.org/10.1037/0003-066X.40.3.266

Haridus- ja Teadusministeerium (2016). Hariduslike erivajadustega õpilaste koolid. Külastatud aadressil https://www.hm.ee/et/tegevused/alus-pohi-ja-keskharidus/ hariduslike-erivajadustega-opilane.

HKS 2014 = Maanso, V., Erelt, T., Kadakas, M., Kala-Arvisto, U., Kraav, I., Puksand, H., Tamm, E., \& Unt, I. (koost.) (2014). Hariduse ja kasvatuse sõnaraamat. Tallinn: Eesti Keele Sihtasutus.

Jørgensen, M., \& Phillips, L. (2002). Discourse analysis as theory and method. London: Thousand Oaks.

Jõgi, L., Karu, K., \& Krabi, K. (2015). Rethinking teaching and teaching practice at university in lifelong learning context. International Review of Education, 61(1), 61-77. doi: http://dx.doi.org/10.1007/s11159-015-9467-z

Kaufman, S. B., \& Sternberg, R. J. (2008). Conceptions of giftedness. In S. I. Pfeiffer (Ed.), Handbook of giftedness in children (pp. 71-92). New York: Springer. doi: http://dx.doi.org/10.1007/978-0-387-74401-8_5

Kitsing, M., Täht, K., \& Kukemelk, H. (2015). Kooli mikrokliima: õpetajate toetav käitumine ja õpilaste tulemuslikkus. Eesti Haridusteaduste Ajakiri, 3(1), 127-147. doi: http://dx.doi.org/10.12697/eha.2015.3.1.06

Kvale, S. (2008). Doing interviews. London: Sage.

Laine, S., \& Tirri, K. (2015). How Finnish elementary school teachers meet the needs of their gifted students. High Ability Studies. Retrieved from http://www.tandfonline.com/doi/full/10.1080/13598139.2015.1108185. doi: http://dx.doi.org/10.1080/13598139.2015.1108185

Loogma, K. (2014). Õpetajate praktika ja klassikeskkond. Ü. Übius, K. Kall, K. Loogma, \& M. Ümarik (toim.), Rahvusvaheline vaade õpetamisele ja óppimisele. OECD 
rahvusvahelise õpetamise ja õppimise uuringu TALIS 2013 tulemused (pp. 112133). Tallinn: Tallinna Ülikooli haridusuuringute keskus.

Mazzoli Smith, L., \& Campbell, J. (2012). Families, education and giftedness: Case studies in the construction of high achievement. Rotterdam: Sense Publishers. doi: http://dx.doi.org/10.1007/978-94-6091-991-6

Mumby, D. K. (1989). Ideology \& the social construction of meaning: A communication perspective. Communication Quarterly, 37(4), 291-304. doi: http://dx.doi.org/10.1080/01463378909385551

Mönks, F. J., \& Pflüger, R. (2005). Gifted education in 21 European countries: Inventory and perspective. Nijmegen: Radboud University Nijmegen. Retrieved from http://www.templetonfellows.org/projects/docs/gifted_education_europe.pdf.

Norwich, B., \& Eaton, A. (2015). The new special educational needs (SEN) legislation in England and implications for services for children and young people with social, emotional and behavioural difficulties. Emotional and Behavioural Difficulties, 20(2), 117-132. doi: http://dx.doi.org/10.1080/13632752.2014.989056

PISA 2012 = Lepmann, T., Jukk, H., Puksand, H., Henno, I., Lindemann, K., Kitsing, M., Täht, K., \& Lorenz, B. (2013). PISA 2012 Eesti tulemused. Eesti 15-aastaste opilaste teadmised ja oskused matemaatikas, funktsionaalses lugemises ja loodusteadustes. Tallinn: SA Innove.

Põhikooli ja gümnaasiumiseadus (2010). Riigi Teataja I 2010, 41, 240. Külastatud aadressil https://www.riigiteataja.ee/akt/13332410.

Põlda, H. (2014). Andekusmõistestik teadus- ja üldkeeles ning andekuse diskursuse diakrooniline konstrueerimine meediatekstides. Tallinna Ülikooli eesti keele ja kultuuri instituudi toimetised 16, 228-253.

Põlda, H. (2015). The linguistic construction of the giftedness discourse in the media texts of historical and digital times. Eesti Rakenduslingvistika Ühingu aastaraamat, 11, 223-239. doi: http://dx.doi.org/10.5128/ERYa11.14

Raud, R. (2013). Mis on kultuur? Sissejuhatus kultuuriteooriasse. Tallinn: Tallinna Ülikooli Kirjastus.

Renzulli, J. (1978). What makes giftedness? Re-examining a definition. Phi Delta Kappan, 60(3), 180-184.

Saul, H., Sepp, V., \& Päiviste, M. (2007). Andekus kui hariduslik erivajadus: olukord Eesti üldhariduskoolides. Tartu Ülikool. Külastatud aadressil http://dspace.ut.ee/bitstream/handle/10062/40910/Uld_Andekus_Eesti.pdf.

Sepp, V. (2010). Andekusest ja andekatest lastest. Tartu: Atlex.

Sternberg, R. J. (2005). The theory of successful intelligence. Interamerican Journal of Psychology, 39(2), 189-202.

Strand, S. (2006). Identifying gifted students: An evaluation of the National Academy for Gifted and Talented Youth (NAGTY) procedure. Occasional Paper, 10. Coventry: CEDAR, University of Warwik. Retrieved from http://dera.ioe.ac.uk/14372/1/occasional-paper10.pdf.

Säälik, Ü. (2012). Kooli ja klassi kliima, õpetaja-õpilase suhted, õpi- ja õpetamismeetodid ning õpetajate käitumine koolijuhi ja õpilaste hinnangute põhjal. J. Mikk, M. Kitsing, O. Must, Ü. Säälik, \& K. Täht (koost.), Eesti PISA 2009 kontekstis: tugevused ja probleemid. Programmi Eduko uuringutoetuse kasutamise lepingu aruanne (lk 62-71). Tartu. 
TALIS 2008 = Loogma, K., Ruus, V-R., Talts, L., \& Poom-Valickis, K. (2009). Õpetaja professionaalsus ning tõhusama õpetamis- ja õppimiskeskkonna loomine. OECD rahvusvahelise õpetamise ja õppimise uuringu TALIS tulemused. Tallinn: Tallinna Ülikooli haridusuuringute keskus.

TALIS 2013 = Übius, Ü., Kall, K., Loogma, K., \& Ümarik, M. (2014). Rahvusvaheline vaade ópetamisele ja óppimisele. OECD rahvusvahelise õpetamise ja óppimise uuringu TALIS 2013 tulemused. Tallinn: SA Innove.

Terasmees, I. (2015). Haridusliku erivajaduse diskursuse konstrueerimine Eesti trükimeedias Postimehe arvamuslugude näitel (magistritöö). Tallinna Ülikool, Tallinn.

Unt, I. (2005). Andekas laps. Tallinn: Koolibri.

Van Dijk, T. A. (2005). Ideoloogia. Multidistsiplinaarne käsitlus. Tartu: Tartu Ülikooli Kirjastus.

Van Leeuwen, T. (1996). The representation of social actors. In C. R. Caldas-Coulthard \& M. Coulthard (Eds.), Texts and practices: Readings in critical discourse analysis (pp. 32-70). London: Routledge.

Vinter, K., Slabina, P., \& Heidmets, M. (2015, 6. veebr.). Õpikäsitus ja koolikultuur. Õpetajate Leht, lk 4. 


\title{
Construction of the meaning of giftedness as a special educational need in the context of the changed learning approach in Estonia
}

\author{
Halliki Põlda ${ }^{\text {al }}$, Katrin Aava ${ }^{a}$ \\ a Tallinn University, School of Humanities
}

\begin{abstract}
Summary
One of the main principles of the Estonian educational policy is the development of all students according to their abilities, including noticing and considering their special educational needs. In the Estonian Lifelong Learning Strategy 2020, a new, more personalised learning approach has been formulated to support the individual and social development of a learner. In Estonia, the education of children with special needs, incl. gifted and talented students, is supported and ensured at national level (see Basic Schools and Upper Secondary Schools Act, 2010²), but there is no comprehensive support system for developing gifted learners. Also, in PISA studies, the lack of work with more gifted learners is pointed out as one of the problems of Estonia.

There are no specific criteria for identifying giftedness (Laine \& Tirri, 2015; Mönks \& Pflüger, 2005); giftedness depends on the sociocultural context (Borland, 1997, 2005; Cigman, 2006; Kaufman \& Sternberg, 2008; Mazzoli et al., 2012). Both our research task and the chosen methodology are based on the viewpoint that giftedness is a social construct that reflects specific forces serving socio-political interests in the education system (Borland, 2005, p. 3).

Our sample consists of oral interviews with five professionally responsible focus groups which were studied as stakeholders: teacher training faculty researchers, officials from education support bodies, education officials from local governments, school headmasters and teachers. The study is qualitatively focussed on how people from those five groups, all responsible in their field of education, understand the notion of special educational needs, underlining giftedness as one of them, according to our laws. The research problem is whether the new learner-centred approach is
\end{abstract}

School of Humanities, Tallinn University, Narva mnt 25, 10120 Tallinn, Estonia;

halliki.polda@tlu.ee

2 See Basic Schools and Upper Secondary Schools Act

https://www.riigiteataja.ee/en/eli/513012014002/consolide (12.01.2016). 
reflected in the understandings of the education stakeholders and how do these stakeholders construct the meaning of giftedness and shape the roles of their own and other participants in the field of education. Our research questions are:

1. How do the focus groups nominate special educational needs, especially giftedness and a gifted learner, and through which discourses are those needs constructed?

2. Which is the common part of the focus-groups' viewpoints and which varieties are present when the stakeholders speak about gifted learners in the context of the changing learning approach?

3. How agentive are the responsible stakeholders as the representatives of certain power structures?

Based on the assumption that the physical world constructed with the help of language acquires a meaning through discourse (Jørgensen \& Phillips, 2002, p. 15) and accounts for the linguistic meanings created for participants, which are used for presenting and establishing social relationships (Fairclough, 2001), the Critical Discourse Analysis has been used as the method of analysing the interviews.

In the estimation of stakeholders, special educational needs are acknowledged; however, there are not enough resources for accommodating the gifted learners. Therefore, our findings on beliefs common for all studied stakeholder groups support the quantitative measurements of PISA, according to which average learners are attended to, but the top learners remain without attention (cf. Säälik, 2012). The lexical analysis also confirmed that - similarly to the education discourse in general (Bernstein, 1996) the discourse of special educational needs designed social identities: in social hierarchy, gifted learners were sometimes placed in the top position, at other times in the lowest position (from genius to a dork and outcast).

When comparing the labels put on gifted learners by the respondents and the names used in theories of giftedness, it was only teachers who mentioned the personal characteristics through which the theoreticians who handle giftedness as a system describe this phenomenon - abilities higher than average, commitment, sophistication, intelligence and creativity (Renzulli, 1978; Sternberg, 2005). Intelligence as the term most often used for describing and measuring gifts only came up during the interviews with teachers (although they used Estonian synonyms for that). The only theory that was referred to was Garnder's theory of multiple intelligences named by education research faculty members. 
Giftedness in education discourse was handled through personal characteristics, not based on developmental aspects (compare Gagné, 2004). Gifted people were rarely described through their own activities (e.g., studies in an untraditional way) or through activities of the others (outcome of teacher's work) but rather through their innate personal characteristics (smart, broad-minded in a natural way).

The representatives of the stakeholders described the situation from their position of an expert-communicator. However, in the majority of situations, the respondents did not identify themselves as agents; in the changing learning situation, the responsible parties were abstract: school, teachers, the gifted learners themselves. Furthermore, the work with gifted learners was also described in an impersonal-passive way (they are left without attention, need to be supported / sent to subject-competitions). Consequently, a gifted learner was verbally turned into an object of activity ((s)he has to be acknowledged / encouraged). Therefore, it can be assumed that the responsible participant groups of education in Estonia do not clearly position themselves as actors of the on-going change.

The common part of the viewpoints of the groups expressed the lack of possibilities (teachers have physically no time, where to find this money). Hence, the results of the present survey support the earlier conclusion that in our education, reality pupils are not encouraged to achieve their whole potential (Kitsing et al., 2015) and these facts were revealed during PISA studies that Estonian education system does not support the development of gifted learners in the classroom (PISA, 2012; Säälik, 2012).

To sum up, the survey indicated the awareness of the responsible participant groups about the problem, but not so much their readiness to act. The present survey also suggests that when it comes to gifted students, the new learner-centred approach is not reflected in the understandings and language used by education stakeholders, the traditional teacher-centred approach being prevalent (as also stated by Jõgi et al., 2015; Loogma, 2014; TALIS, 2008). Nevertheless, the teachers who participated in the survey saw the high potential of a gifted learner, describing him/her in the most versatile way. Meanwhile, there are some pre-requisites for introducing the changed learning approach on a broader scale. Every responsible group studied some discourse which indicated a readiness for changing course, supporting the implementation of the changed learning approach, although the same discourses were absent in other groups' interviews, or on the contrary, appeared simultaneously in two groups. Those more hidden discourses may provide the basis for a broader dialogue needed in the field to realise the idea of the new type of education (see Mumby, 1989 on the 
prerequisites for cultural change). Therefore, cooperation in the society and creating a meaning to the changed learning approach is important for education stakeholders, helping them to support the individual development of all students, including talented ones.

Keywords: special educational need, giftedness, gifted learner, changed learning approach, critical discourse analysis 